\title{
PELATIHAN SMCP TERHADAP KEMAMPUAN BAHASA INGGRIS MARITIM CALON PELAUT DI KECAMATAN BENGKALIS
}

\author{
Aprizawati*1, Suzdayan ${ }^{2}$ \\ ${ }^{1}$ Program Studi Ketatalaksanaan Pelayaran Niaga, Jurusan Kemaritiman Politeknik Negeri \\ Bengkalis \\ ${ }^{2}$ Program Studi Nautika, Jurusan Kemaritiman, Politeknik Negeri Bengkalis \\ *E-mail: aprizawati@ polbeng.ac.id
}

\begin{abstract}
This service is carried out the aim of improving Maritime English language skills using the SMCP (Standard Marine Communication Phrases) application for prospective seamen in Bengkalis sub-district. The dedication partners are shipping alumni from Bengkalis sub-district, both at the level of secondary school and academy or polytechnic level. This activity was carried out on several factors, namely lack of information and knowledge about Maritime English; less varied learning methods, empowerment of improving Maritime English language skills not socialized by local governments, unstable community economy. In this activity, it is expected that prospective seamen in Bengkalis sub-district can improve their maritime English proficiency and be able to take a state examination in taking seafarers' certificates. This activity was attended by 20-25 participants from various shipping alumni in Bengkalis, carried out during 8 meetings at the Maritime English Laboratory, Department of Maritime, Bengkalis State Polytechnic. As for the results of this community service activity, the participants were very active and successfully solved all the problems that were applied to the SMCP learning
\end{abstract}

Keywords-SMCP, Maritime English, Seamen

\begin{abstract}
Abstrak
Pengabdian ini dilaksanakan dengan tujuan meningkatkan kemampuan berbahasa Inggris Maritim menggunakan aplikasi SMCP (Standard Marine Communication Phrases)bagi calon pelaut yang ada di kecamatan Bengkalis. Adapun mitra pengabdian ini adalah alumni pelayaran yang berasal dari kecamatan Bengkalis baik setingkat Sekolah menengah maupun setingkat akademi atau politeknik. Kegiatan ini dilaksanakan atas beberapa faktor yaitu kurangnya informasi dan pengetahuan tentang Bahasa Inggris Maritim, Metode pembelajaran kurang variatif, pemberdayaan peningkatan kemampuan berbahasa Inggris Maritim tidak disosialisikan oleh pemerintah daerah, Ekonomi masyarakat yang tidak stabil. Dalam kegiatan ini diharapkan calon-calon pelaut di kecamatan Bengkalis bisa meningkatkan kemampuan berbahasa Inggris Maritim dan bisa mengikuti ujian negara dalam pengambilan sertifikat pelaut. Kegiatan ini diikuti sebanyak 20-25 peserta dari berbagai alumni pelayaran di Bengkalis, dilaksanakan selama 8 kali pertemuan di Laboratorium Bahasa Inggris Maritim, Jurusan Kemaritiman Politeknik Negeri Bengkalis. Adapun hasil kegiatan pengabdian ini adalah peserta sangat aktif dan berhasil menyelesaikan semua persoalan yang diaplikasikan pada pembelajaran SMCP.
\end{abstract}

Kata Kunci-SMCP, Bahasa Inggris Maritim, Pelaut

\section{PENDAHULUAN}

Bahasa Inggris merupakan bahasa yang sering digunakan untuk berkomunikasi di kapal terutama dengan orang-orang asing, selain berkomunikasi dengan orang asing, bahasa inggris juga sering dipakai dalam aktivitas keseharian di kapal, terlebih lagi apa bila bekerja di kapal-kapal internasional maka kemungkinan besar bahasa yang digunakan untuk berkomunikasi di kapal, baik itu mengoperasikan, aba-aba, informasi atau berbicara menggunakan bahasa inggris, oleh karena itu selama ada kesempatan untuk belajar bahasa inggris maka sebaiknya usahakan untuk bisa 
mempraktekkannya. Salah satu contoh dalam mengucapkan abjad menggunakan istilah Alfa untuk A, Brave untuk B, dan seterusnya yang tertuang di buku ajar untuk ATT V atau ANT V. [2]

Dengan memiliki kemampuan berbahasa inggris maka memungkinkan untuk bisa masuk ke kapal-kapal yang beroperasi sampai keluar negeri (internasional), seperti saat ini memang sangat di dahulukan dan dipentingkan sekali untuk bisa bahasa inggris, pada suatu saat kita melamar di perusahaan pelayaran, terlebih lagi jika perusahaan internasional maka akan ada tes-tes tertentu dengan menggunakan bahasa inggris. Untuk menjadi seorang pelaut internasional yang bekerja di kapal-kapal berbendera Eropa, Amerika atau Australia, maka seorang pelaut harus memahami Standard Marine Commmunication Phrases (Kalimat-Kalimat Baku Komunikasi Laut) atau yang lebih dikenal dengan SMCP. Berdasarkan Konvensi Internasional STCW 1978 (revisi 1995) SMCP menjadi syarat bagi para perwira -- meskipun hanya beroperasi di kapal nasional -- yang bertugas melaksanakan pengawasan navigasi kapal di atas 500GT. [8]

Meskipun sudah bekerja di kapal pun bukan berarti tidak memerlukan bahasa inggris, akan tetapi harus tetap meningkatkan kemampuan dalam berbahasa inggris, karena dengan adanya bisa berbahasa inggris maka mempermudah pada saat melamar di perusahaan pelayaran dan memungkinkan untuk mendapatkan kapal yang beroperasi internasional. Secara umum bahasa inggris itu memang sangat diperlukan baik untuk kerja di darat maupun di kapal, yang bertujuan untuk memudahkan dan memungkinkan untuk bisa mendapatkan pekerjaan hingga sampai internasional, jadi sudah bekerja atau belum bekerja di kapal pun setidaknya bisa mempelajari serta meningkatkan kemampuan dalam berbahasa inggris agar mempermudah dalam mencari kapal, setidaknya belajar bahasa inggris sedikit demi sedikit dan dengan jalannya waktu kemungkinan akan menjadi bisa berbahasa inggris. Seperti dikutip dalam buku Tenkner in Daniele (2014) yang menjelaskan bahwa "The entirety of all those means of the English language which, being used as a device for communication within the International maritime community, contribute to the safety navigation and the facilitation of the seaborne trade. The focus of research on Maritime English has so far been mostly confined to various aspects of language pedagogy. [6] Kutipan ini bermaksud bahwa Bahasa Inggris merupakan bahasa yang digunakan untuk berkomunikasi di komunitas pelayaran internasional. Adapun Bahasa Inggris maritime merupakan Bahasa Inggris yang sering digunakan oleh para kadet di kapal untuk berkomunikasi di atas kapal dengan menggunakan istilah-istilah pelayaran. [3]

Di Bengkalis, ada beberapa institusi pendidkan tinggi yang juga membutuhkan pembelajaran Bahasa Inggris dalam pendidikannya. Akan tetapi tidak semua menyediakan pembelajaran Bahasa Inggris maritime secara khususnya. Bahasa Inggris secara umum menjadi momok menakutkan dan bahasa yang seolah-olah harus dijauhkan dari kehidupan padahal dalam kehidupan nyata Bahasa Inggris umum dan bahasa Inggris yang dikhususkan seperti Bahasa Inggris maritime merupakan salah satu penunjang dalam meningkatkan perekonomian masyarakat khususnya yang tinggal di pesisir pantai dan bekerja sebagai pelaut. Adapun istilah dalam Bahasa Inggris Maritim ini berbeda dengan Bahasa Inggris secara umumnya, hal ini diungkapkan pada penelitian yang menyatakan The terms make no sense out of maritime English or they are incomprehensible or wired. For example, the phrase "hard a port" cannot be understood according to literal meanings, however, in maritime English it denotes certain meaning.[1]

Ada beberapa faktor menyebabkan Bahasa Inggris Maritim menjadi kurang popular dalam penggunaannya antara lain yaitu:

1. Kurangnya informasi dan pengetahuan tentang Bahasa Inggris Maritim

2. Metode pembelajaran yang kurang variatif.

3. Pemberdayaan peningkatan kemampuan berbahasa Inggris Maritim tidak disosialisikan oleh pemerintah daerah.

4. Ekonomi masyarakat yang tidak stabil.

Menurut pra-observasi yang telah dilakukan, selain belajar Bahasa Inggris Maritim di sekolah atau kampus, tidak ada tempat khusus yang memberikan pelatihan atau pembelajaran untuk peningkatan kemampuan berbahasa Inggris Maritim. Hanya beberapa calon pelaut saja yang mampu dan berkesempatan mengikuti tes-tes Bahasa Inggris yang sifatnya Internasional secara online. Itupun diikuti oleh pelaut-pelaut yang memang memiliki kemampuan baik dari segi ekonomi ataupun skill dan pengalaman berlayar yang sudah go Internasional. Selain itu, ada 
beberapa mahasiswa yang juga sering menghadapi masalah dalam Bahasa Inggris Maritim yang kesulitan mencari wadah sebagai problem solving. Dari beberapa materi bacaan yang dipelajari tentang topic-topik yang di bahas mengenai Bahasa Inggris Maritim merupakan materi-materi terampil penggunaan kosakata dalam istilah pelayaran. [10] Melihat kondisi seperti diatas maka salah satu langkah yang perlu diambil adalah dengan membuat penerapan SMCP bagi peningkatan mutu Bahasa Inggris Maritim bagi pelaut yang ada di Kecamatan Bengkalis yang membutuhkan. Penerapan SMCP yang dimaksud adalah dalam bentuk pelatihan secara berkelanjutan setiap minggunya selama 3 bulan berturut-turut. Dimulai dari pemberian pre-test, materi dan post-test. Pelatihan akan dilaksanakan di labor Bahasa Inggris maritime Jurusan Kemaritiman dengan pemateri yang sudah memiliki sertifikat keahlian bidang pelayaran seperti T.O.T 6.09 dan T.O.E 3.12.

Untuk melaksanakan program ini tentu kami tidak bisa sendiri. Kegiatan ini dilaksanakan dengan kerjasama Alumni Pelayaran dimana para alumni yang kebanyakan kerja sebagai pelaut tersebut memiliki data-data pelaut yang ada di kecamatan Bengkalis baik yang sudah bertukar profesi menjadi pekerja kantoran atau yang masih aktif berlayar. Mengacu kepada butir analisa situasi, permasalahan mitra untuk kelompok Bahasa Inggris mencakup hal-hal sebagai berikut:

a. Belum pernah ada pelatihan khusus Bahasa Inggris Maritim di Kecamatan Bengkalis

Belum adanya wadah untuk menampung keinginan masyarakat yang ingin menambah pengetahuan tentang ESP (Englih for Specific purposes) khususnya Bahasa Inggris Maritim.

b. Belum memiliki tempat khusus dan fasilitas memadai bagi pelatihan Bahasa Inggris Maritim.

Sampai saat ini yang terlihat adalah menjamurnya tempat kursus bahasa Inggris umum, sedangkan untuk Bahasa Inggris Maritim itu sendiri belum memiliki wadah untuk pengadaannya. Akan tetapi pelatihan ini akan dimudahkan denan menumpang sementara di labor BIM jurusan kemaritiman Politeknik Negeri Bengkalis di Simpang ayam.

c. Faktor ekonomi masyarakat rata-rata menengah kebawah.

Tingkat ekonomi masyarakat di Bengkalis rata-rata menengah kebawah sehingga sulit untuk memenuhi kebutuhan mereka untuk bisa mendapat kelas tambahan/kursus Bahasa Inggris Maritim atau mengambil kursus khusus BIM seperti Marlin Test atau pembelajaran SMCP secara resmi yang sesuai dengan SOP dan diakui secara internasional.

\section{METODE}

Upaya mengatasi permasalahan yang ada, tim pengabdi menawarkan metode pendekatan yang merupakan solusi dalam kegiatan IbM. [9]. Metode yang digunakan adalah pelatihan / penyuluhan / bimbingan teknis / pendampingan yang sesuai dengan kebutuhan dan keinginan dari para alumni. Adapun solusi Penerapan SMCP dalam Bahasa Inggris Maritim adalah sebagai berikut:

a Setiap calon pelaut harus memiliki pemahaman yang baik terhadap cara berkomunikasi yang baik dan layak di atas kapal menggunakan standar yang diperlukan

b. Setiap calon pelaut berhak mendapatkan pelatihan khusus baik teoritis ataupun praktikal tentang SMCP guna meningkatkan kemampuan mereka dalam olah bahasa sehingga bisa bersaing dalam dunia kemaritiman secara global.

c. Setiap calon pelaut bisa menjadi income bagi masyarakat karena dapat bekerja sampai ke luar negeri dan menjadi kebanggaan dalam masyarakat melalui skill bahasa yang akan dimiliki.

d. Tim pengabdian kepada masyarakat memberikan pendidikan dan pelatihan dalam mengaji pengembangan dan penerapan SMCP sesuai dengan kebutuhan masyarakat dari hasil pemetaan.

e. Tim pengabdian kepada masyaraka memberikan pelatihan bagaimana sistem penggunaan kalimat, pengucapan serta praktek berbahasa dan kemampuan mengoperasikan computer dengan baik dalam menggunakan aplikasi SMCP tersebut.

f. Tim pengabdian kepada masyaraka memberikan Pelatihan Bahasa Inggris Maritim dengan menggunakan SMCP

Sedangkan target yang dicapai dalam pengabdian adalah:

TARGET 1 yaitu memfasilitasi pengadaan kursus gratis Bahasa Inggris Maritim dengan 
menggunakan SMCP. Adapun target luarannya sebagai berikut:

a. Mitra mendapatkan buku panduan/ modul Bahasa Inggris Maritim secara gratis.

b. Mitra mengikuti kursus gratis.

TARGET 2 yaitu peningkatan motivasi belajar mitra terhadap Bahasa Inggris Maritim. Adapun target luarannya sebagai berikut:

a. Mitra mendapatkan metode pembelajaran Bahasa Inggris Maritim yang inovatif sesuai dengan tingkatan pemasalah yang ingin mendapatkan treatment Bahasa Inggris tersebut.

b. Mitra mendapatkan motivasi belajar Bahasa Inggris Martim yang aplikatif.

TARGET 3 yaitu membantu para pelaut dan calon pelaut yang kurang informasi dan kurang biaya sebelum berangkat untuk pengambilaan sertifikat layar.

Prosedur kerja / langkah langkah untuk mendukung realisasi metode yang ditawarkan sebagai berikut:

1. Melakukan rapat koordinasi Tim Pelaksana,

2. Menyiapkan calon Mitra

3. Menyusun jadwal kegiatan program Pengabdian Masyarakat

4. Pelaksanaan kegiatan :

a. Fasilitasi penyiapan tempat kursus

b. Pengadaan modul

c. Persiapan pengajaran

d. Pelaksanaan pengajaran

5 .

Pelaksanaan monitoring dan evaluasi. [4]

Adapun kegiatan yang dilakukan dijelaskan sebagai berikut:

1. Studi lapangan ke calon mitra

Sebelum mengusulkan program, pengusul melakukan studi lapangan ke tempat calon mitra. Dalam melakukan studi ini akan dipergunakan metoda survey observasi, wawancara, dan checklist data pada instansi terkait. Studi dilakukan melihat langsung permasalahan yang ada dilapangan.

2. Melihat dan menganalisis permasalahan yang ada

Pengurus Ikatan Alumni Pelayaran di Bengkalis belum memahami, tugas dan tangung jawab pengurus, belum mengetahui konsep penggunaan BIM dengan baik, serta mempraktekkannya di lapangan.

3. Justifikasi permasalahan yang dihadapi

Berdasarkan pantauan di lapangan perlu pendidikan dan pelatihan bagi calon pelaut yang pernah mengecap pendidikan di bidang pelayaran yang dapat diarahkan melalui praktek berbahasa serta pengembangan standar berkomunikasid yang bersifat publik, sehingga memberi dampak positif terhadap pembangunan ekonomi masyarakat.

Dengan di selengarakannya pendidikan dan pelatihan dari pihak-pihak terkait, peserta pelatihan yang kelak menjadi pelaut bisa mempraktekkan kemampuan mereka dan lulus dalam mengikuti ujian Negara untuk memudahkan mendapat sertifikat di bidang pelayaran.

1. Perencanaan, pemanfaatan dan pengembangan SMCP

Identifkasi merupakan langkah-langkah yang harus dilakukan oleh calon pelaut, meliputi pemetaan standard dan level skill berbahasa melalui pretest BIM di labor mnggunakan SMCP serta permasalahan yang dihadapi calon pelaut.

2. Pemetaan kebutuhan

Merupakan proses penerapan SMCP setelah dilakukan pre-test dan melihat level berbahasa Inggris Maritim, baik di level bawah, menengah dan atas sehingga bisa memetakan kondisi kelas 
untuk diberikan pelatihan dan penerapan SMCP.

3. Indetifikasi potensi

Merupakan suatu lanjutan dari aktifitas pemetaan hasil penerapan pre- test SMCP selanjutnya akan diberikan treatment secara mendalam agar mendapatkan hasil yang maksimal pada posttestnya.

\section{Penerapan SMCP}

a. Pendampingan

Memberikan pendampingan kepada alumni pelayaran dalam pelaksanaan penerapan SMCP terhadap kemampuan Bahasa Inggris Maritim bagi calon pelaut

b. Pelatihan teknis

Pelatihan Teknis disini memberikan berberapa pengetahuan dan pemahaman terhadap Bahasa Inggris maritime menggunakan aplikasi SMCP.

c. Laporan Hasil

Setelah dilakukan sosialisasi dan pembekalan kepada calon pelaut, maka pihak perguruan tinggi akan mengevaluasi perkembangan peserta pelatihandalam berkomunikasi serta kemampuan assessment menggunakan aplikasi SMCP tersebut, melaporkan perkembangan kemampuan Bahasa Inggris Maritim mereka yang dapat meningkatkan skill berbahasa Inggris yang baik bagi pelaut- pelaut yang akan datang khususnya di kabupaten Bengkalis.

\section{HASIL DAN PEMBAHASAN}

Kegiatan pengabdian kepada masayarakat dengan tema "Pelatihan dan Bimbingan SMCP (Standard Marine Communication Phrase) Terhadap Kemampuan Bahasa Inggris Maritim Pelaut Di Kecamatan Bengkalis" telah dilaksanakan mulai tanggal 24 Agustus sampai dengan tanggal 20 September 2019 di Desa Simpang Ayam Kecamatan Bengkalis Kabupaten Bengkalis dengan melibatkan peserta pelatihan alumni pelayaran yang ada di kecamatan Bengkalis.

Adapun hasil pre-test dan post-test dari pelatihan SMCP ini adalah sebagai berikut:

Tabel 1. Hasil Pre-test dan Post-test

\begin{tabular}{ccccc}
\hline Peserta & Pre-test & Post-test & $\mathrm{d}$ (selisih) & $\mathrm{d}^{2}$ \\
\hline 1 & 65 & 82 & 17 & 289 \\
\hline 2 & 63 & 81 & 18 & 324 \\
\hline 3 & 69 & 87 & 18 & 324 \\
\hline 4 & 59 & 80 & 21 & 441 \\
\hline 5 & 61 & 81 & 20 & 400 \\
\hline 6 & 55 & 76 & 21 & 441 \\
\hline 7 & 70 & 87 & 17 & 289 \\
\hline 8 & 72 & 84 & 12 & 144 \\
\hline 9 & 63 & 79 & 16 & 256 \\
\hline 10 & 66 & 82 & 16 & 256 \\
\hline 11 & 60 & 80 & 20 & 400 \\
\hline 12 & 71 & 86 & 15 & 225 \\
\hline 13 & 74 & 88 & 14 & 196 \\
\hline 14 & 62 & 79 & 17 & 289 \\
\hline 15 & 73 & 92 & 19 & 361 \\
\hline
\end{tabular}


DINAMISIA - Jurnal Pengabdian Kepada Masyarakat Vol. 3, No. 2 Desember 2019, Hal. 291-298

\begin{tabular}{ccccc}
\hline 16 & 59 & 82 & 23 & 529 \\
\hline 17 & 68 & 83 & 15 & 225 \\
\hline 18 & 55 & 80 & 25 & 625 \\
\hline 19 & 75 & 87 & 12 & 144 \\
\hline AVERAGE & 56 & 71 & 15 & 225 \\
& 64.8 & 82.35 & 17.55 & \multirow{2}{*}{6383} \\
\hline STD. DEVIASI & 1296 & 5.048 & & \\
\hline MINIMUM & 53 & 71 & & \\
\hline MAKSIMUM & 75 & 92 & & \\
\hline
\end{tabular}

Pada tahun 2016 perbah ada penelitian yang melipatkan penggunaan Bahasa Inggris Maritim dengan menggunakan Authentic Assessment Bridge Simulator [5]. Dalam hal ini tim pengabdian menggunakan SMCP guna meningkatkan kemampuan Bahasa Inggris Maritim (BIM). Secara umum kegiatan pelaksanaan Pelatihan dan Bimbingan SMCP (Standard Marine Communication Phrase) Terhadap Kemampuan Bahasa Inggris Maritim Pelaut Di Kecamatan Bengkalis berjalan dengan lancar. Peserta yang mengikuti kursus ini sangat antusias belajar Bahasa Inggris Maritim menggunakan aplikasi SMCP. Menurut buku ajar MarineSoft GmbH in SMCP Tools Module, the SMCP Training Tools terdiri dari beberapa bagian penting yang harus diketahui peserta antara lain Basic Drill part A, part B, content training, multimedia training, dan lain lain.[7] Hal ini membuat peserta menjadi antusias untuk mempelajari lebih lanjut hal ini juga ditandai dengan kehadiran mereka datang ke kampus maritime di desa Simpang Ayam walaupun hampir semua bukan berdomisili di desa tersebut. Mereka telah disediakan kendaraan untuk dibawa ke tempat kegiatan berlangsung. Dalam proses pembelajarannya banyak peserta yang aktif bertanya untuk hal-hal yang belum mereka pahami dan mereka kelihatan sangat serius dan selalu menantikan pertemuanpertemuan selanjutnya.

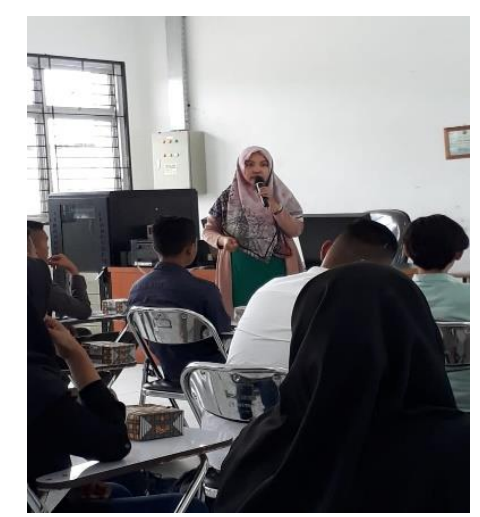

Gambar 1. Pembukaan Pelatihan dan Bimbingan SMCP

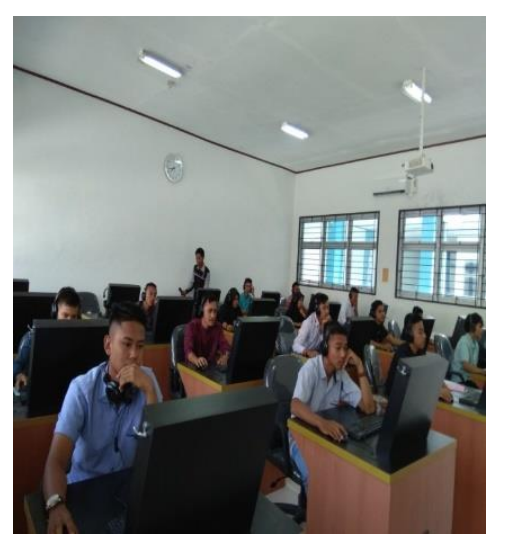

Gambar 2. Kegiatan Pelatihan dan Bimbingan SMCP 


\section{KESIMPULAN}

Kegiatan pengabdian kepada masyarakat dengan tema "Pelatihan dan Bimbingan SMCP (Standard Marine Communication Phrase) Terhadap Kemampuan Bahasa Inggris Maritim Pelaut Di Kecamatan Bengkalis" dimulai pada tanggal 24 Agustus sampai dengan tanggal 20 September 2019. Kegiatan Pelatihan dan Bimbingan SMCP (Standard Marine Communication Phrase) Terhadap Kemampuan Bahasa Inggris Maritim Pelaut Di Kecamatan Bengkalis tersebut menggunakan metode yang applicable dan teknologi komputer. Dengan metode tersebut peserta lebih mudah mengerti dan cepat mengingat kosakata serta komunikasi yang telah dipelajari sehingga teknik tersebut efektif membangun motivasi mereka untuk belajar Bahasa Inggris Maritim. Ada beberapa peserta yang berdomisili brdekatan dengan rumah tutor langsung datang untuk mendiskusikan materi yang belum mereka pahami sepenuhnya dan selalu muncul pada ujian Negara untuk pelaut.

Walaupun secara umum pelaksanaan kegiatan "Pelatihan dan Bimbingan SMCP (Standard Marine Communication Phrase) Terhadap Kemampuan Bahasa Inggris Maritim Pelaut Di Kecamatan Bengkalis" berjalan lancar, tetapi tim juga menghadapi beberapa kendala. Diantaranya: 1. Kehadiran peserta yang mengikuti kursus.

Dalam hal ini tidak setiap pelaksanaan kursus siswa yang hadir dalam jumlah yang sama. Hal ini dikarenakan: Beberapa peserta telah naik kapal untuk bekerja

2. Faktor cuaca

Secara langsung cuaca yang kurang bersahabat (kabut asap) membuat peserta tidak bisa hadir.

3. Faktor kendaraan

Peserta tidak datang tepat waktu sehingga kendaraan untuk mengangkut tidak digunakan semaksimal mungkin. Mereka menyusul sendiri tapi memakan waktu yang lama sehingga kegiatan jadi terganggu.

\section{SARAN}

Secara umum kegiatan tersebut berjalan dengan lancar walaupun ada penurunan jumlah peserta yang hadir. Hal tersebut disebabkan karena faktor tidak displin dalam waktu dan perubahan cuaca sehingga diharapkan untuk kegiatan pengabdian selanjutnya permasalahan tersebut bisa diatasi dengan cara bekerjasama dengan pihak terkait untuk memberikan kontribusi yang apik dalam pelaksanaan kegiatan pengabdian ini.

\section{UCAPAN TERIMA KASIH}

Penulis mengucapkan terima kasih kepada Politeknik Negeri Bengkalis yang telah memberi dukungan financial terhadap pengabdian ini melalui program PNBP.

\section{DAFTAR PUSTAKA}

[1] Aprizawati and Zahraa, Safra Apriani. The Making Of E-Mar Learning Application With Android Based System. ICTE 2 vol. 2017

[2] B. Saman, Rachmat and Judy Koesprijanto. (2003). Bahasa Inggris Maritim untuk Program ANT V dan ATT V. LembagaPendidikanKepelautan (LPK), Semarang.

[3] Blakey, T.N. (1987). English for Maritime Studies Second Edition.Pergamon Press.

[4] Direktorat Riset dan Pengabdian kepada Masyarakat. 2017. Panduan Pelaksanaan Penelitian dan Pengabdian Kepada Masyarakat di Perguruan Tinggi Edisi X, Kementerian Riset, Teknologi dan Pendidikan Tinggi.

[5] Fauzi, Ahmad, PattaBundu, SurandiTahmir. (2016) The development of Maritime English Learning Model Using Authentic Assessment based Bridge Simulator in Merchant Marine 
DINAMISIA - Jurnal Pengabdian Kepada Masyarakat Vol. 3, No. 2 Desember 2019, Hal. 291-298

Polythecnic, Makassar. International Journal of Environmental and Science Education, Vol. 11 no. 10, 3231-3240.

[6] Franceshi, Daniele. (2014). The Features of Maritime English Discourse. International Journal of English Linguistics.

[7] IMO\&Rijeka College of maritime Studies.2000. IMO Standard Marine Communication Phrases. NAV 46.INF.4

[8] International Transport Workers' Federation. STCW, a Guide for Seafarers, Taking into account the 2010 Manila amendments. www.itfglobal.org

[9] Pusat Penelitian dan Pengabdian Masyarakat. 2017. Panduan Pelaksanaan Penelitian dan Pengabdian Masyarakat Sumber Dana PNBP. Politeknik Negeri Bengkalis

[10] SMK Pelayaran Panggali Nusantara. Bahasa Inggris Maritim untuk ANT IV. Palemban. 